\title{
Vulnerability assessment of Central-East Sardinia (Italy) to extreme rainfall events
}

\author{
A. Bodini ${ }^{1}$ and Q. A. Cossu ${ }^{2,1}$ \\ ${ }^{1}$ Institute of Applied Mathematics and Information Technology, Milan, Italy \\ ${ }^{2}$ Sardinian Environmental Protection Agency, Sassari, Italy
}

Received: 24 July 2009 - Revised: 16 November 2009 - Accepted: 10 December 2009 - Published: 14 January 2010

\begin{abstract}
In Sardinia (Italy), the highest frequency of extreme events is recorded in the Central-East area (3-4 events per year). The presence of high and steep mountains near the sea on the central and south-eastern coast, causes an EastWest precipitation gradient in autumn especially, due to hot and moist currents coming from Africa. Soil structure and utilization make this area highly vulnerable to flash flooding and landslides. The specific purpose of this work is to provide a description of the heavy rainfall phenomenon on a statistical basis. The analysis mainly focuses on i) the existence of trends in heavy rainfall and ii) the characterization of the distribution of extreme events. First, to study possible trends in extreme events a few indices have been analyzed by the linear regression test. The analysis has been carried out at annual and seasonal scales. Then, extreme values analysis has been carried out by fitting a Generalized Pareto Distribution (GPD) to the data. As far as trends are concerned, different results are obtained at the two temporal scales: significant trends are obtained at the seasonal scale which are masked at the annual scale. By combining trend analysis and GPD analysis, the vulnerability of the study area to the occurrence of heavy rainfall has been characterized. Therefore, this work might support the improvement of land use planning and the application of suitable prevention systems. Future work will consider the extension of the analysis to all Sardinia and the application of statistical methods taking into account the spatial correlation of extreme events.
\end{abstract}

\section{Introduction}

In the Mediterranean area, the existence of trend in precipitation and particularly in heavy rainfall, is not yet clearly assessed. Yearly precipitation trends are negative in the

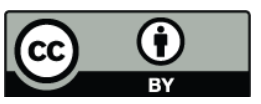

Correspondence to: A. Bodini (antonella.bodini@mi.imati.cnr.it) east, while they are not significant in the west (Norrant and Douguédroit, 2006). Contrasting trends have been highlighted between an increase in the central Mediterranean (Italy) and a decrease over the Balkans (Kostopoulou and Jones, 2005). Increased contributions of torrential rainfall (>64 mm per day) to the total annual rainfall have been observed in Spain and Italy, but not in Israel and Cyprus (Alpert et al., 2002). A high variability of results has been obtained in Italy as well: an analysis of 67 sites of daily precipitation records over the 1951-1996 period, shows that insular zones have often opposite results to the peninsular ones, where the rainfall is slightly decreasing during autumn and winter (Brunetti et al., 2001).

Changes in climate such as increases or decreases in rainfall or temperature can radically change landscapes, and therefore climate studies are fundamental for the biodiversity conservation, for instance (Walther et al., 2002). Moreover, as precipitation patterns change, limited capacity for water storage may need to be increased to capture a greater proportion of winter rainfall, because of heavy demands on limited water resources for a variety of needs - for fresh water supply, agriculture, industry, and sustaining healthy ecosystems (Vörösmarty et al., 2000; Miller and Yates, 2005; Ludi, 2009).

As far as the climate of Sardinia is concerned, the literature provides several references that describe both temperature and rainfall regimes, see for instance Delitala et al. (2000). In contrast, the literature about climate change appears to be much less complete and more fragmented: some paleoclimatic analyses have been carried out in Antonioli et al. (2003) and in Montagna et al. (2004). Duce and co-authors recently considered possible effects of climate change on agriculture, but their analysis is based on climatic projections from IPCC scenarios, and does not consider historical data (see for instance Duce et al., 2006). In the previously mentioned paper, Brunetti and co-authors analyse the climatic variability in Italy during the second half of 20th century, but only three out of the about 200 meteorological

Published by Copernicus Publications on behalf of the European Geosciences Union. 
stations available in Sardinia are considered (Capo Bellavista, Cagliari and Sassari). These stations are very far from each other so that, due to the complex orography of the island, the results coming from this analysis cannot be considered as fully representative. Therefore, an extended analysis of Sardinian rainfall has been undertaken focusing on trends. In this paper we present the results obtained for Central-East Sardinia, the area of Sardinia recording the highest frequency of extreme events. In the past and in this area, extreme events like the 1951 flood (14-19 October) resulted in rain accumulation that was comparable with monthly or even yearly averages. In the last five years in particular, several exceptional events occurred, often producing flash floods. In November 2008, even two severe events caused floods in the same area: to face heavy damages to private houses, household goods, public infrastructure and agriculture, the Regional Government allocated over 70 million $€$ (source: Regional Government of Sardinia).

The aim of this work is to statistically analyse possible rainfall trends with emphasis on the occurrence and intensity of extreme events. This joint analysis, which is not usual in the relevant literature, can provide a few indications useful to define the areas which are highly vulnerable to the occurrence of extreme events, on a statistical basis. In fact, extreme events are one of the main components concurring to define the hydrogeological risk. Hydrogeological risk is indeed the term commonly used to sum up the effects of naturally-occurring physical phenomena implying the possibility of a loss or damage for human life, assets, activities and production capacity. The composite nature of this definition requires a multi-disciplinary approach and this work should be considered as an essential part of any procedure aiming at assessing hydrological hazard in Sardinia. To our knowledge, no studies have been undertaken to date about flood or landslide triggering factors in Sardinia, and this work should represent a starting point.

\section{Study area}

Sardinia is the second largest island of the Mediterranean. With a forest cover of $50.36 \%$, higher than the national average, and $1870 \mathrm{~km}$ of coastal development, Sardinia represents an ecoregion of the central Mediterranean, together with Sicily, Corsica and Malta. It hosts 25000 species of plants and about $75 \%$ of the insects in Europe, as well as a high number of endemic species. These features have made tourism the primary economic activity in Sardinia and therefore, the environmental knowledge and preservation must be of primary importance.

The study area is shown in Fig. 1. It includes most part of the Province of Ogliastra and is divided into three hydrologic basins. The analysis focuses on the basin named hereafter Coastal Basin (indicated as "Minori tra Cedrino e Flumendosa" in Fig. 1); a few neighbouring stations to

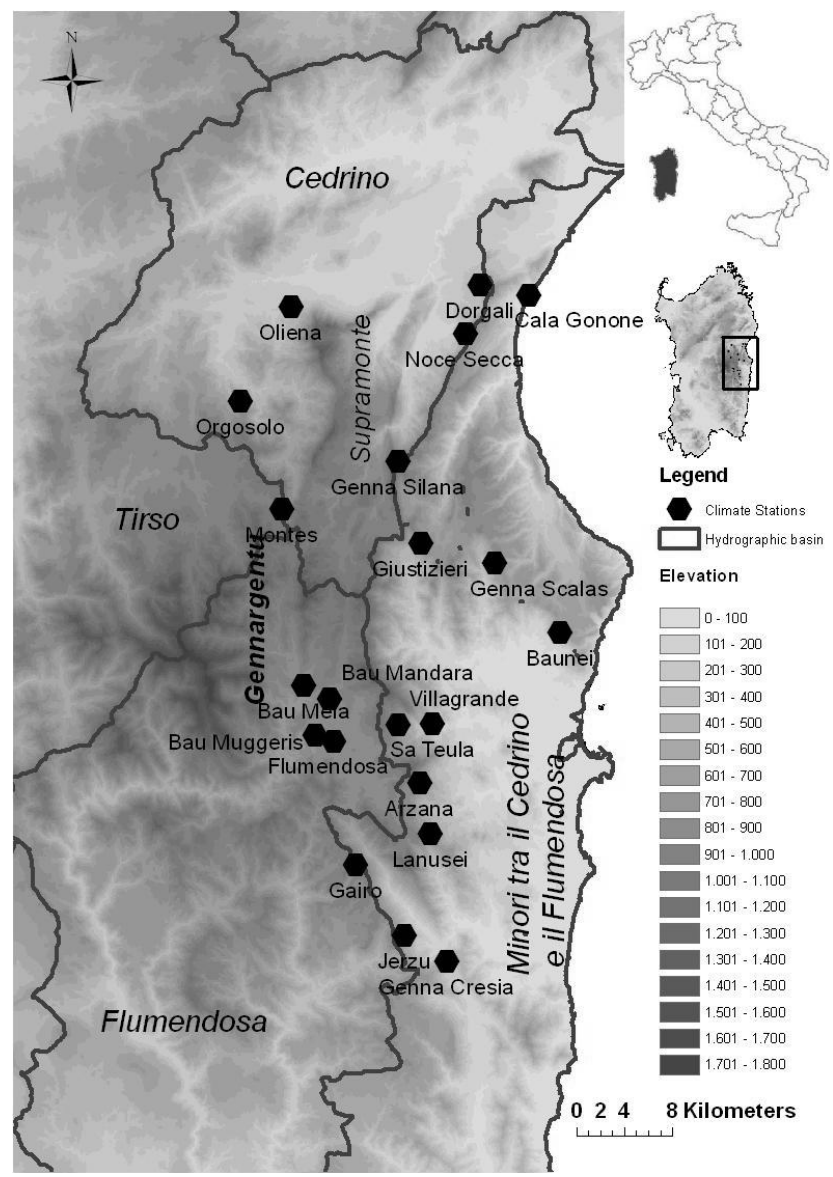

Fig. 1. Location of the meteorological stations, on an orographic representation of the study area obtained by a Digital Elevation Model. The darker the colour the higher the altitude.

the north (Cedrino Basin) and west (Flumendosa Basin) have also been selected to provide a complete overview of the area, which thus includes important mountainous areas of Sardinia (Supramonte and Gennargentu mountain group, $1828 \mathrm{~m}$ a.s.l.). An elevation of over $1000 \mathrm{~m}$, steep slopes (up to $40 \%)$ and a short distance from the sea $(10-15 \mathrm{~km})$ give indeed rise to an important orography which, together with rock structure and soil permeability, makes the study area vulnerable to weather conditions. For a geomorphological description of the area see De Waele (2008).

In autumn and winter especially, the Coastal Basin is strongly affected by a particular synoptic situation which corresponds to a European blocking, characterized by a split of westerly flow at all levels. A part of the Atlantic flow is forced to pass over Northern Africa and, due to cyclonic circulation, it crosses the southern part of the Mediterranean Sea, increasing its potential instability because of the relatively high sea surface temperature (Chessa et al., 1999). This flow finally impinges on the eastern part of Sardinia, where the steep mountains lying near the coastline, allow orographically induced precipitations that decrease with an 
Table 1. Geographic characteristics of the considered pluviometric stations. In brackets, short notation for stations names.

\begin{tabular}{|c|c|c|c|c|c|c|c|c|}
\hline Basin & Station & $\begin{array}{l}\text { UTM } \\
\text { Est }\end{array}$ & $\begin{array}{l}\text { UTM } \\
\text { Nord }\end{array}$ & $\begin{array}{l}\text { Sea Dist. } \\
\text { (m) }\end{array}$ & $\begin{array}{l}\text { Altitude } \\
\text { (m a.s.1.) }\end{array}$ & $\begin{array}{l}\text { Slope } \\
(\%)\end{array}$ & $\begin{array}{c}\text { Aspect } \\
(\text { polar degrees, } 0=\mathrm{N})\end{array}$ & $\begin{array}{c}\text { Aspect } \\
\text { (East-West) }\end{array}$ \\
\hline \multirow{9}{*}{$\begin{array}{l}\text { 岕 } \\
\text { 恶 } \\
0\end{array}$} & Arzana (AR) & 545220 & 4418935 & 13927 & 674 & 21.38 & 105.26 & East \\
\hline & Baunei (BA) & 556830 & 4431475 & 3287 & 480 & 18.56 & 225.00 & West \\
\hline & Cala Gonone (C.G.) & 554250 & 4459575 & 46 & 25 & 17.00 & 143.97 & East \\
\hline & Genna Cresia (G.C.) & 547430 & 4404065 & 9928 & 272 & 38.24 & 258.69 & West \\
\hline & Genna Silana (G.S.) & 543330 & 4445715 & 10915 & 1010 & 14.25 & 52.13 & East \\
\hline & Jerzu $(\mathrm{J})$ & 543880 & 4406265 & 13712 & 550 & 3.54 & 45.00 & East \\
\hline & Lanusei (L) & 546040 & 4414695 & 12288 & 595 & 35.58 & 18.43 & East \\
\hline & Sa Teula C. (S.T.C.) & 546200 & 4423875 & 12407 & 251 & 14.28 & 113.20 & East \\
\hline & Villagrande (V) & 543350 & 4423775 & 15257 & 679 & 23.35 & 74.48 & East \\
\hline \multirow{5}{*}{ 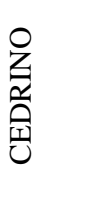 } & Dorgali (D) & 550160 & 4460385 & 3972 & 387 & 11.86 & 288.43 & West \\
\hline & Noce Secca (N.S.) & 548990 & 4456365 & 4161 & 504 & 45.63 & 359.22 & West \\
\hline & Oliena $(\mathrm{O})$ & 534460 & 4458585 & 18841 & 378 & 12.02 & 332.10 & West \\
\hline & Montes (M) & 533700 & 4441725 & 21314 & 1060 & 23.54 & 100.71 & East \\
\hline & Orgosolo (OR) & 530200 & 4450705 & 23148 & 591 & 19.04 & 23.20 & East \\
\hline \multirow{4}{*}{ 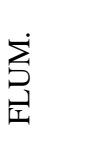 } & Gairo $(\mathrm{G})$ & 539860 & 4412145 & 18612 & 784 & 10.08 & 299.74 & West \\
\hline & Bau Mandara (B.MA) & 537650 & 4425925 & 21067 & 812 & 5.59 & 206.57 & West \\
\hline & Bau Mela (B.ME) & 535550 & 4427025 & 23184 & 812 & 40.48 & 76.61 & East \\
\hline & Bau Muggeris (B.MU) & 536500 & 4422925 & 22122 & 820 & 21.29 & 183.37 & West \\
\hline
\end{tabular}

East-West gradient. Precipitation is here more intense than in other areas of Sardinia: major rain storms often follow dry periods and can succeed each other at short intervals and with the same epicentre, causing therefore serious environmental damage, deaths, the destruction of houses, land and dead cattle. The important geomorphic changes following the more recent floods, like modifications of the rivers bed morphology or movements of great quantities of sediment which have led to a visible landscape modification in many areas, have been studied in Cossu et al. (2007) and in Cossu et al. (2009b).

\section{Data and methods}

\subsection{Data}

We analysed daily rainfall data referring to the period 1951-2000, collected at 18 Governmental Hydrographic Service mechanic pluviometric stations and available at the Sardinian Environmental Protection Agency (henceforth ARPAS, Agenzia Regionale per la Protezione dell'Ambiente della Sardegna, in Italian). These stations, listed in Table 1, have at least 40 years worth of data, except for Arzana (39) and Villagrande (31) and do not present long gap of consecutive years. Data were not adjusted for inhomogeneities, but stations were originally quality checked by ARPAS and further by the authors, through the analysis of the temporal and spatial coherence of several summaries of the data, including the indices analysed in the following. This procedure allowed to discard four stations (Gairo, Lanusei, Montes and Orgosolo) from trend analysis; for more details, see Bodini and Cossu (2008). Annual records containing more than $8 \%$ missing values (about one month) were discarded. Remaining years were further checked, to discard those with short gaps due to the possible occurrence of extreme events. The spatial coherence of the latter was also examined, looking for an explanation (e.g., different local orography) of possible particular behaviours. If such an explanation was not found, those days were considered as missing.

\subsection{Methods}

A threshold of $1 \mathrm{~mm}$ has been applied to define a rainy day (e.g. Brunetti et al., 2004; Frich et al., 2002). The following indices have been considered at the annual scale:

- relative frequency of rainy days ( $\geq 1 \mathrm{~mm}), \mathrm{F}$;

- total precipitation, TP;

- mean precipitation in a rainy day, or precipitation intensity, PI;

- daily maximum, M;

- maximum 5-day precipitation total; R5D

- percentile of order 0.95 (calculated from wet days), q95;

- relative frequency of days with precipitation $\geq 10 \mathrm{~mm}$; R10;

- maximum number of consecutive dry days $(<1 \mathrm{~mm})$, CDD. 
The relative frequency of rainy days and the total precipitation have been considered at the seasonal scale as well, together with the proportion of annual accumulation and annual number of rainy days due to each season. Four seasons have been considered: January-March (JFM), AprilJune (AMJ), July-September (JAS), and October-December (OND). In Sardinia, a winter season ranging from October to March can be identified (see for instance, Chessa et al., 1999). However, in Bodini and Cossu (2008) differences in the rainfall pattern between the periods OND and JFM have been found which justify the choice of separating the two sub-periods. Similar arguments suggested to separate spring (AMJ) from summer (JAS). An instance of these differences is shown in Fig. 2, and briefly discussed in Sect. 4.1.

Finally, extreme events are here defined as daily totals above the 1951-2000 95th percentile (calculated from wet days), and their behaviour is described at the annual scale by considering:

- annual accumulation, TEP (total extreme precipitation);

- proportion of annual accumulation due to extreme events, defined as TEP/TP, EP (extreme proportion);

- mean of extreme events, EI (extreme intensity).

To define a daily amount as extreme, we chose a sitedependent threshold, so that differences among the stations are better taken into account (see Haylock and Nicholls, 2000).

A few remarks about the adopted indices are necessary. CDD, R5D, R10 and PI correspond to four of the five indicators suggested by Frich et al. (2002) for monitoring change in climatic extremes world-wide, and listed by the joint Working Group on Climate Change Detection of the World Meteorological Organization - Commission for Climatology (WMO - CCL) together with the Research Programme on Climate Variability and Predictability (CLIVAR. See Peterson et al., 2001). EP is very similar to the fifth indicator, i.e. the fraction of annual precipitation exceeding the 19611990 95th percentile. The difference between the quantiles computed over the two periods is often negligible, and therefore the two indices can be considered as equivalent. Here, $\mathrm{R} 10$ is defined as a proportion rather than an absolute frequency, to take into account the different record lengths, due to missing data. To compute R5D, the rainfall is totalled over 5 consecutive days regardless of how many days are missing in that period. To compute CDD, only complete years have been used.

Linear trends have been checked by the linear regression test with statistical significance equal to 0.05 . Due to the high interannual variability, a sensitivity analysis of the influence of very high/low values has been carried out and trends have been considered as significant if they persisted after removing such data.
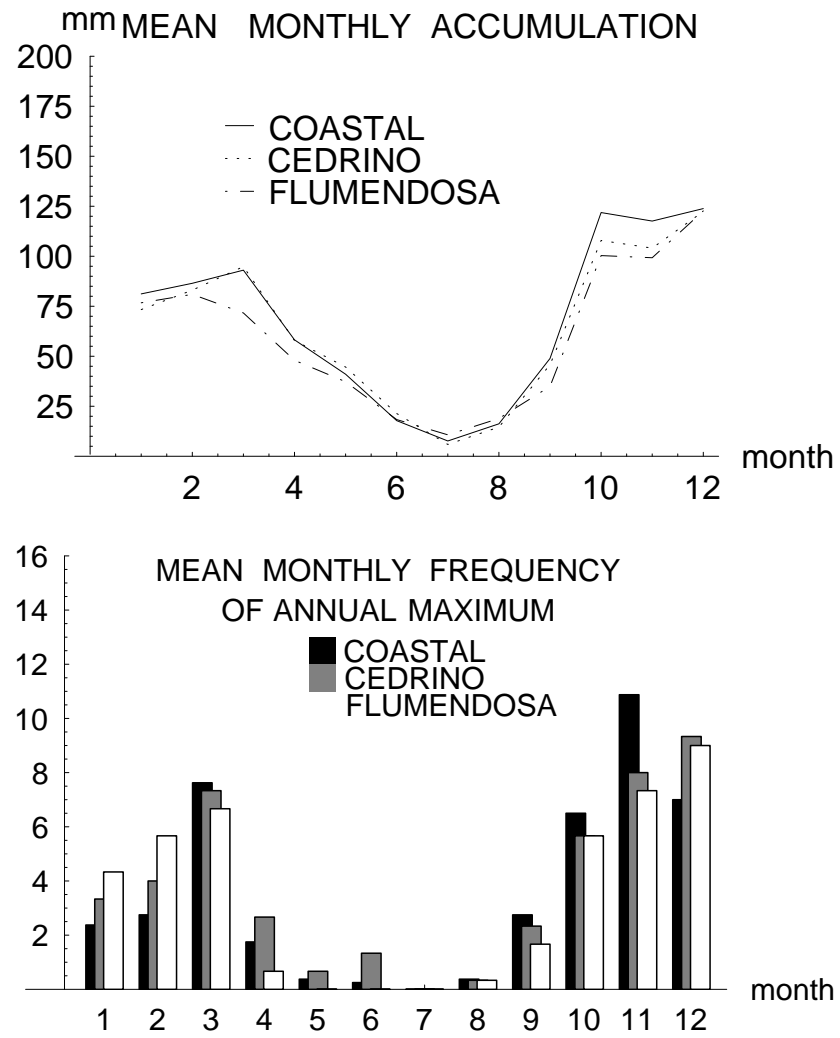

Fig. 2. Mean monthly accumulation (top) and mean frequency of annual maximum occurrence per month (bellow): mean values are averaged with respect to the membership basin.

Gamma distributions have been fitted to wet days, according to Osborn and Hulme (2002). However, a poor fit was generally obtained, due to the presence of very high values that cannot be accounted for, by the tails of the Gamma family. This confirms the need of modelling daily rainfall data by a different distribution, as suggested in Betrò et al. (2008). Therefore, we limited our attention to modelling heavy rainfall, by applying the Extreme Values Theory. Due to the shortness of annual time series, an analysis over threshold has been preferred, to reduce the information wastage induced by the analysis of annual maxima only. Based on asymptotic theory, a Generalized Pareto Distribution (GPD)

$$
\begin{aligned}
\mathrm{P}\left(X_{i}-u>x \mid X_{i}>u\right) & =(1+\xi x / \sigma)^{-1 / \xi} & & \text { if } \xi \neq 0 \\
& =\exp (-x / \sigma) & & \text { if } \xi=0
\end{aligned}
$$

approximates the distribution of excesses (or exceedances) $X_{i}-u$ for a large enough threshold $u$, where $X_{i}$ denotes independent and identically distributed daily rainfall amounts. The validity of such approximation also for dependent random variables has been proved by Leadbetter (1974), provided that there is no long-range dependence of high-level exceedances. Parameter $\xi$ in (1) coincides with the shape 
Table 2. Relevant climatic values at the selected stations: period 1951-2000.

\begin{tabular}{|c|c|c|c|c|c|c|c|c|c|c|c|c|c|c|}
\hline Basin & Station & $\begin{array}{c}\text { Record } \\
\mathrm{n}\end{array}$ & $\begin{array}{c}\mathrm{F} \\
\mathrm{n}^{*}\end{array}$ & $\begin{array}{c}\mathrm{TP} \\
\mathrm{mm}\end{array}$ & $\begin{array}{c}\mathrm{M} \\
\mathrm{mm}\end{array}$ & $\begin{array}{c}\text { PI } \\
\mathrm{mm}\end{array}$ & $\begin{array}{c}\mathrm{R} 5 \mathrm{D} \\
\mathrm{mm}\end{array}$ & $\begin{array}{c}\mathrm{R} 10 \\
\mathrm{n}^{*}\end{array}$ & $\begin{array}{c}\text { CDD } \\
n\end{array}$ & $\begin{array}{l}\mathrm{q}_{95} \\
\mathrm{~mm}\end{array}$ & $\begin{array}{l}\text { TEP } \\
\mathrm{mm}\end{array}$ & $\begin{array}{c}\mathrm{EP} \\
\%\end{array}$ & $\begin{array}{c}\mathrm{EI} \\
\mathrm{mm}\end{array}$ & $\begin{array}{c}\mathrm{EF} \\
\mathrm{n}\end{array}$ \\
\hline \multirow{8}{*}{ 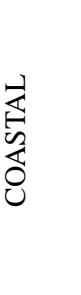 } & Arzana & 39 & 75.2 & 1020.9 & 141.5 & 13.5 & 244.5 & 25.0 & 57.3 & 49.3 & 396.8 & 36.2 & 88.5 & 4.3 \\
\hline & Baunei & 49 & 63.1 & 973.8 & 140.3 & 15.3 & 251.4 & 23.2 & 63.7 & 62.0 & 369.9 & 33.9 & 96.4 & 3.4 \\
\hline & Cala Gonone & 42 & 64.0 & 625.5 & 79.0 & 9.6 & 138.7 & 18.2 & 58.6 & 34.8 & 221.4 & 32.4 & 56.3 & 3.7 \\
\hline & Genna Cresia & 47 & 65.0 & 932.1 & 126.7 & 14.3 & 222.3 & 25.5 & 68.7 & 50.5 & 340.0 & 32.2 & 83.4 & 3.6 \\
\hline & Genna Silana & 42 & 79.3 & 1110.8 & 146.9 & 14.1 & 247.8 & 27.5 & 50.3 & 53.7 & 429.9 & 34.9 & 96.1 & 4.1 \\
\hline & Jerzu & 44 & 76.6 & 860.7 & 98.9 & 11.2 & 164.0 & 23.9 & 62.1 & 39.8 & 297.3 & 31.9 & 67.0 & 4.4 \\
\hline & Sa Teula Centrale & 47 & 72.0 & 976.0 & 136.3 & 13.5 & 232.1 & 25.2 & 57.9 & 48.4 & 387.9 & 35.8 & 92.0 & 4.2 \\
\hline & Villagrande & 31 & 60.2 & 1067.7 & 150.8 & 17.8 & 258.3 & 27.8 & 74.0 & 66.7 & 380.3 & 32.3 & 110.0 & 3.2 \\
\hline \multirow{3}{*}{ تِّن } & Dorgali & 47 & 60.7 & 841.4 & 122.8 & 14.1 & 212.7 & 20.7 & 67.4 & 53.6 & 315.0 & 32.4 & 86.0 & 3.2 \\
\hline & Noce Secca & 40 & 60.7 & 883.8 & 127.5 & 14.4 & 218.8 & 22.4 & 66.0 & 55.4 & 319.7 & 33.1 & 92.8 & 3.1 \\
\hline & Oliena & 48 & 56.1 & 740.8 & 102.4 & 13.2 & 180.5 & 21.8 & 70.8 & 42.7 & 252.1 & 29.6 & 75.2 & 3.1 \\
\hline \multirow{3}{*}{ 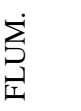 } & Bau Mandara & 40 & 70.1 & 784.7 & 90.5 & 11.2 & 152.6 & 22.8 & 63.2 & 37.1 & 271.8 & 29.6 & 61.5 & 3.8 \\
\hline & Bau Mela & 41 & 70.3 & 810.4 & 108.8 & 11.5 & 175.6 & 23.0 & 61.2 & 38.7 & 299.2 & 31.7 & 70.4 & 3.7 \\
\hline & Bau Muggeris & 43 & 75.2 & 823.8 & 111.0 & 10.8 & 185.6 & 21.4 & 55.0 & 38.5 & 309.5 & 32.5 & 72.2 & 3.9 \\
\hline
\end{tabular}

* Mean proportion $\cdot 365.25$.

parameter of the Generalized Extreme Values (GEV) distribution which can be fitted to annual maxima,

$\mathrm{P}\left(\max _{1 \leq i \leq n} X_{i} \leq z\right)=\exp \left\{-[1+\xi(z-\mu) / \sigma]^{-1 / \xi}\right\}$

with $-\infty<\xi, \mu<+\infty, \sigma>0$ and $\{z: 1+\xi(z-\mu) / \sigma>0\}$. Therefore, in (1) Fréchet-type $(\xi>0)$, Weibull-type $(\xi<0)$ and Gumbel $(\xi=0)$ distributions can be recognized. Scale parameter $\sigma$ in (1) differs from the analogous term in (2), even if they are related. The threshold $u$ is usually chosen by a visual inspection of both mean residual life plots and plots of the estimated parameters as functions of $u$. Possible trends and seasonality can also been included in model (1). For details, see Coles (2001, Ch. 4).

The toolkit extRemes (Gilleland and Katz, 2005) of the free software $\mathrm{R}$ has been used for computations.

\section{Results}

\subsection{Climate of the study area}

Table 2 reports climatic values of several indices. Compared with Table 1, it shows that stations at the highest altitudes have the highest annual accumulations, according to previous studies. However, this analysis highlights a few peculiarities of the study area with respect to the rest of Sardinia. The most rainy month in the Coastal Basin is indeed October rather than December. Moreover, the March accumulation can be as important as the highest accumulation in autumn. The monthly frequency distribution of annual maximum has a bimodal pattern, with an absolute mode in either November or December, rarely in October, and a relative mode in
March, rarely in February. Figure 2 compares the basin averages of the monthly accumulation and of the monthly frequency of annual maxima.

In slightly more detail, looking at Table 2 we can highlight that:

a) the highest total precipitations $(>1000 \mathrm{~mm})$ are reached at Arzana, Villagrande and Genna Silana, which are close to the watershed lines and located at the highest altitudes. Arzana and Genna Silana show the highest number of rainy days per year ( $\geq 75)$, while only 60 days per year are obtained at Villagrande: this contributes to make maximum the precipitation intensity at this station;

b) Sa Teula Centrale and Baunei have total precipitation close to $1000 \mathrm{~mm}$, despite the lower altitude;

c) Baunei and Villagrande show the highest extreme percentiles, q95. As percentiles of lower order do not vary substantially among the stations (see Bodini and Cossu, 2008), we can conclude that the daily rainfall distribution has here the heaviest tails. This result is partially confirmed by the GPD analysis (see Sect. 4.3);

d) Villagrande, Baunei and Genna Silana show the highest extreme intensities (>95 mm);

e) at Arzana, Jerzu, Sa Teula Centrale and Villagrande more than four extreme events per year occur.

Summing up, Arzana, Baunei, Genna Silana, Sa Teula Centrale and Villagrande can be preliminary identified as the most vulnerable of the stations to heavy rainfall, on a statistical basis. 


\subsection{Trends}

The Coastal Basin, which is the area of the main interest in this work, shows a substantial lack of trends at the annual scale, as reported in Table 3. However, a diverse situation appears at the seasonal scale (see Table 4): decreasing precipitations are obtained in winter (JFM), while in autumn (OND) a few significant trends are only concerning index F. This is particularly important as OND is the period of highest frequency of extreme events. On the contrary, in summer (JAS) and at a lesser extent in spring, the contributions to annual values of TP and F increase. These results suggested to deepen the analysis by examining R5D in autumn and winter, in order to check if precipitations are decreasing due to decreasing extreme precipitations, and by examining CDD in spring and summer, to verify if increased precipitations are able to reduce the length of dry periods. A reduction of R5D in JFM was found, corresponding to decreasing TP, while no trends were found in AMJ and JAS, despite increasing F.

As far as stations neighbouring the Coastal Basin are concerned, Table 3 highlights that those in the Flumendosa Basin show significant decreasing trends in several indices. The opposite sign trend in the frequency of rainy days at Dorgali could imply some kind of error, and therefore we will abstain from any comment on the respective observed trends. In the Flumendosa Basin, decreasing annual accumulations (TP) are observed together with decreasing indices of heavy rainfall (M, R5D, TEP and EI). However, Table 4 suggests that this result can be due to changes in the winter rainfall regime: in JFM, more decreasing trends than in OND are obtained. In particular, decreasing trends are obtained for R5D with significance slightly higher than 0.05 . Increasing trends for CDD are obtained in spring (AMJ).

In Table 3, differences between early 1950s and late 1990s are also indicated, for significant trends. Relative frequencies are normalized for the number of missing days. These values have to be considered as an indication, rather than as a trend quantification. Indeed, noticeable differences in TP or TEP for instance, are often caused by the occurrence of extreme events of exceptional intensity in 1951 and, more in general, in early 1950s. Particularly high values obtained for stations in the Flumendosa Basin can question the obtained results, and suggest lack of homogeneity rather than an effective climate change signal. From all the checks we carried out, we could simply argue that if changes or transfers of rain gauges have occurred, they occurred almost simultaneously and caused the same effect on all the three stations. Researches, we conducted in collaboration with Regional Authorities, were not sufficient to find any useful information, however the statistical analysis we are conducting on other stations of the same basin highlights, that all the basin is affected by trends, see Cossu et al. (2009a).
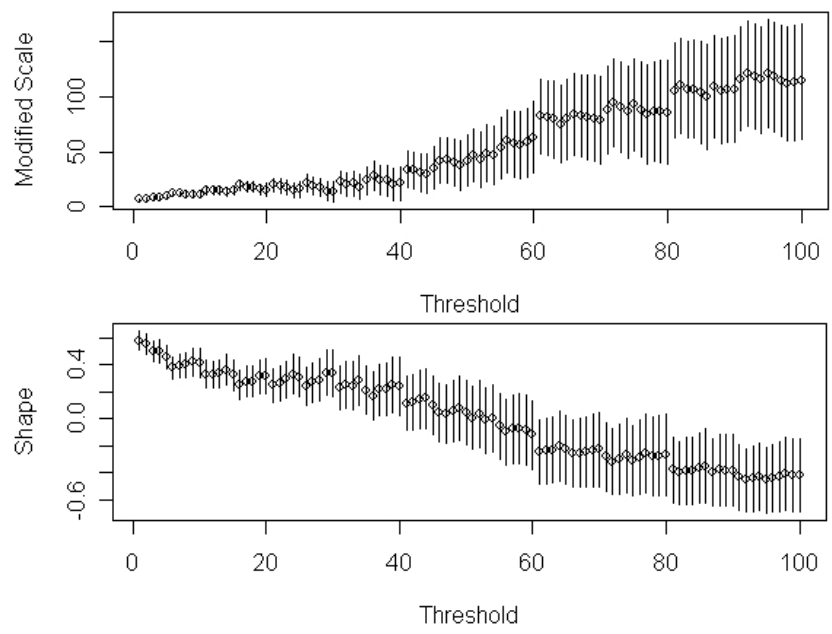

Fig. 3. Plot of estimated GPD parameters $\xi$ (below) and $\sigma$ (top) as functions of threshold $u$, at annual scale. According to the theory, linearity would be expected. Vertical bars represent the variance of the estimates as function of $u$.

\subsection{GPD analysis of heavy rainfall}

As illustrated in Sect. 4.2, both Coastal and Cedrino basins show a substantial lack of significant trends in the indices we considered to describe heavy rainfall. This permitted to carry out the GPD analysis under the hypothesis of stationarity. Owing to observed trends in the Flumendosa Basin, a linear trend in the location parameter of the GEV model for annual maxima has been considered $\left(\mu(t)=\mu_{0}+\mu_{1} t\right.$, see (2)) and its significance checked by likelihood ratio test: the $p$-value is always $>0.50$ and therefore we can assume that trends reported in Sect. 4.2 do not have impact on the extreme values models. A trend in the GEV model rather than in the adopted GPD model has been considered as the behaviour of the annual maximum series turns out to be generally consistent with that of the series over threshold (see Sect. 3.2). Seasonality was significant (likelihood ratio test) for almost all the stations as expected, and then we concentrated on the period from September to April, the period of highest occurrence of heavy rainfall. As far as Noce Secca is concerned, both the mean residual life plot and the plots of estimated parameters ( $\xi$ and $\sigma$ ) against the threshold $u$ suggested that the GPD model is not adequate. The latter plots are displayed in Fig. 3: from the Extreme Value theory, linearity is expected for well-fitting models (see Coles, 2001, Ch. 4.).

Summing up, a GPD analysis has been carried out on seasonal data under the hypothesis of stationarity for all but one of the stations. Table 5 reports the adopted thresholds: these are lower than values $\mathrm{q}_{95}$ used in the previous Sections to describe extreme events (see Table 2). Indeed, modelling requires more data, i.e. lower thresholds, to guarantee good estimates (narrow confidence intervals). 
Table 3. Significant trends $(p<0.05)$ of indices at the annual scale. $\dagger$ : increase. - : decrease. Symbols + and - indicate trends with significance in $[0.05,0.10]$. In brackets, variation from early 1950 s to late $1990 \mathrm{~s}$, according to Sect. 4.2. Frequencies are normalized for missing data.

\begin{tabular}{|c|c|c|c|c|c|c|c|c|c|c|c|c|c|c|}
\hline \multirow[b]{2}{*}{ Index } & \multicolumn{8}{|c|}{ COASTAL } & \multicolumn{3}{|c|}{ CEDRINO } & \multicolumn{3}{|c|}{ FLUMENDOSA } \\
\hline & $\mathrm{AR}$ & BA & C.G. & G.C. & G.S. & $\mathrm{J}$ & S.T.C. & $\mathrm{V}$ & $\mathrm{D}$ & N.S. & $\mathrm{O}$ & B. MA & B. ME & B. MU \\
\hline $\mathrm{F}$ & $\begin{array}{c}- \\
(13.6)\end{array}$ & & & & $\begin{array}{c}- \\
(12.0)\end{array}$ & & & $\begin{array}{c}- \\
(19.2)\end{array}$ & $\begin{array}{c}\dagger \\
(10.2)\end{array}$ & & - & $\begin{array}{c}- \\
(9.6)\end{array}$ & $\begin{array}{c}- \\
(26.6)\end{array}$ & - \\
\hline $\mathrm{TP}$ & & & & $\begin{array}{c}- \\
(198.7)\end{array}$ & & - & $\begin{array}{c}- \\
(153.0)\end{array}$ & & - & & & $\begin{array}{c}- \\
(288.2)\end{array}$ & $\begin{array}{c}- \\
(338.0)\end{array}$ & $\begin{array}{c}- \\
(177.8)\end{array}$ \\
\hline PI & & & & & & & & & $\begin{array}{c}- \\
(11.6)\end{array}$ & & & & & \\
\hline \multicolumn{15}{|l|}{ CDD } \\
\hline M & & & & & & & & & & & & $\begin{array}{c}- \\
(64.2)\end{array}$ & - & - \\
\hline R5D & & & & & & & & & & & & $\begin{array}{c}- \\
(218.8)\end{array}$ & $\begin{array}{c}- \\
(220.1)\end{array}$ & $\begin{array}{c}- \\
(179.6)\end{array}$ \\
\hline $\mathrm{q}_{95}$ & & & & & & & & & $\begin{array}{c}- \\
(54.9)\end{array}$ & & & & & \\
\hline $\mathrm{R} 10$ & & & & & & & & & & & & & $\begin{array}{c}- \\
(3.8)\end{array}$ & \\
\hline TEP & & & & & & & & & $\begin{array}{c}- \\
(487.4)\end{array}$ & & & $\begin{array}{c}- \\
(305.2)\end{array}$ & $\begin{array}{c}- \\
(268.6)\end{array}$ & $\begin{array}{c}- \\
(482.9)\end{array}$ \\
\hline EP & & & & & & & & & $\begin{array}{c}- \\
(24)\end{array}$ & & & & & $\begin{array}{c}- \\
(25.7)\end{array}$ \\
\hline EI & & & & & & & & & & & & $\begin{array}{c}- \\
(12.3)\end{array}$ & & $\begin{array}{c}- \\
(29.0)\end{array}$ \\
\hline
\end{tabular}

Table 4. Significant trends $(p<0.05)$ for indices at the seasonal scale. $\dagger$ : increase. - : decrease. Symbols + and - indicate trends with significance in $[0.05,0.10]$.

\begin{tabular}{|c|c|c|c|c|c|c|c|c|c|c|c|c|c|c|c|c|c|c|c|c|c|}
\hline \multirow[t]{2}{*}{ Basin } & \multirow[t]{2}{*}{ Station } & \multicolumn{5}{|c|}{ JFM } & \multicolumn{5}{|c|}{ AMJ } & \multicolumn{5}{|c|}{ JAS } & \multicolumn{5}{|c|}{ OND } \\
\hline & & $\mathrm{TP}$ & F & $\mathrm{TP} / \mathrm{y}$ & $\mathrm{F} / \mathrm{y}$ & R5D & $\mathrm{TP}$ & F & $\mathrm{TP} / \mathrm{y}$ & $\mathrm{F} / \mathrm{y}$ & CDD & $\mathrm{TP}$ & $\mathrm{F}$ & $\mathrm{TP} / \mathrm{y}$ & $\mathrm{F} / \mathrm{y}$ & CDD & $\mathrm{TP}$ & F & $\mathrm{TP} / \mathrm{y}$ & $\mathrm{F} / \mathrm{y}$ & R5D \\
\hline \multirow{7}{*}{ 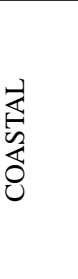 } & $\mathrm{AR}$ & & - & & & & & & & & & & & + & & & & - & & & \\
\hline & BA & & - & & & & & & & + & & & & & & & & & & & \\
\hline & C.G. & - & - & & & - & & & & + & & + & $\dagger$ & $\dagger$ & $\dagger$ & & & - & & & \\
\hline & G.C. & - & - & & - & & & $\dagger$ & & $\dagger$ & & & & $\dagger$ & + & & & - & & & \\
\hline & G.S. & & - & & & & & & & & & & & $\dagger$ & $\dagger$ & & & - & & & \\
\hline & $\mathrm{J}$ & - & - & & - & & & & & + & & & & $\dagger$ & $\dagger$ & & & & & & \\
\hline & $\begin{array}{l}\text { S.T.C. } \\
\mathrm{V}\end{array}$ & - & - & & & - & & & & + & & & & + & $\dagger$ & & & 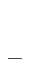 & & & \\
\hline \multirow{3}{*}{ 总 } & $\mathrm{D}$ & - & & & & _ & & $\dagger$ & & $\dagger$ & & & & $\dagger$ & & & & & & & \\
\hline & N.S. & & & & & & & $\dagger$ & & $\dagger$ & & $\dagger$ & & & & & & & & - & \\
\hline & $\mathrm{O}$ & & - & & & & & & & & & & & $\dagger$ & & & & - & & & \\
\hline \multirow{3}{*}{ 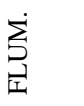 } & B.MA & - & - & & & - & & & & & $\dagger$ & & & $\dagger$ & & & - & - & & & - \\
\hline & B.ME & - & - & & & - & - & - & & & $\dagger$ & & & & & & - & - & & & \\
\hline & B.MU & - & - & & - & - & & & & + & & $\dagger$ & $\dagger$ & $\dagger$ & $\dagger$ & & & - & & & \\
\hline
\end{tabular}


Table 5. Seasonal analysis: GPD estimated thresholds and parameters. Exceedances numbers are indicated as absolute frequencies and percentages (in brackets) with respect to all the complete records. CIs are based on the profile likelihood method.

\begin{tabular}{|c|c|c|c|c|c|c|}
\hline Basin & Station & $\begin{array}{c}u \\
(\mathrm{~mm})\end{array}$ & $\begin{array}{c}\text { exceedances } \\
\mathrm{n}(\%)\end{array}$ & $\xi$ & $95 \% \mathrm{CI}(\xi)$ & $\sigma$ \\
\hline \multirow{8}{*}{ 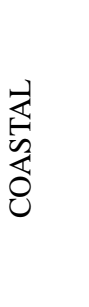 } & Arzana & 30 & $254(3 \%)$ & 0.27 & $(0.13,0.44)$ & 28.77 \\
\hline & Baunei & 50 & $188(2 \%)$ & 0.05 & $(-0.09,0.24)$ & 46.04 \\
\hline & Cala Gonone & 25 & $188(2 \%)$ & 0.006 & $(-0.12,0.18)$ & 25.29 \\
\hline & Genna Cresia & 27 & $334(3 \%)$ & 0.30 & $(0.17,0.47)$ & 24.85 \\
\hline & Genna Silana & 35 & $248(2 \%)$ & 0.12 & $(-0.01,0.29)$ & 42.17 \\
\hline & Jerzu & 20 & $405(4 \%)$ & 0.27 & $(0.15,0.41)$ & 19.59 \\
\hline & Sa Teula C. & 20 & $427(4 \%)$ & 0.27 & $(0.16,0.41)$ & 25.02 \\
\hline & Villagrande & 25 & $234(4 \%)$ & 0.21 & $(0.07,0.40)$ & 34.47 \\
\hline \multirow{3}{*}{ 䆥 } & Dorgali & 27 & $318(3 \%)$ & 0.18 & $(0.05,0.33)$ & 30.95 \\
\hline & Noce Secca & - & - & - & - & - \\
\hline & Oliena & 30 & $191(2 \%)$ & 0.20 & $(0.06,0.40)$ & 31.20 \\
\hline \multirow{3}{*}{ 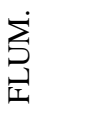 } & Bau Mandara & 17 & $336(4 \%)$ & 0.47 & $(0.29,0.60)$ & 13.97 \\
\hline & Bau Mela & 30 & $163(2 \%)$ & 0.26 & $(0.09,0.49)$ & 31.85 \\
\hline & Bau Muggeris & 25 & $227(3 \%)$ & 0.37 & $(0.20,0.60)$ & 23.90 \\
\hline
\end{tabular}
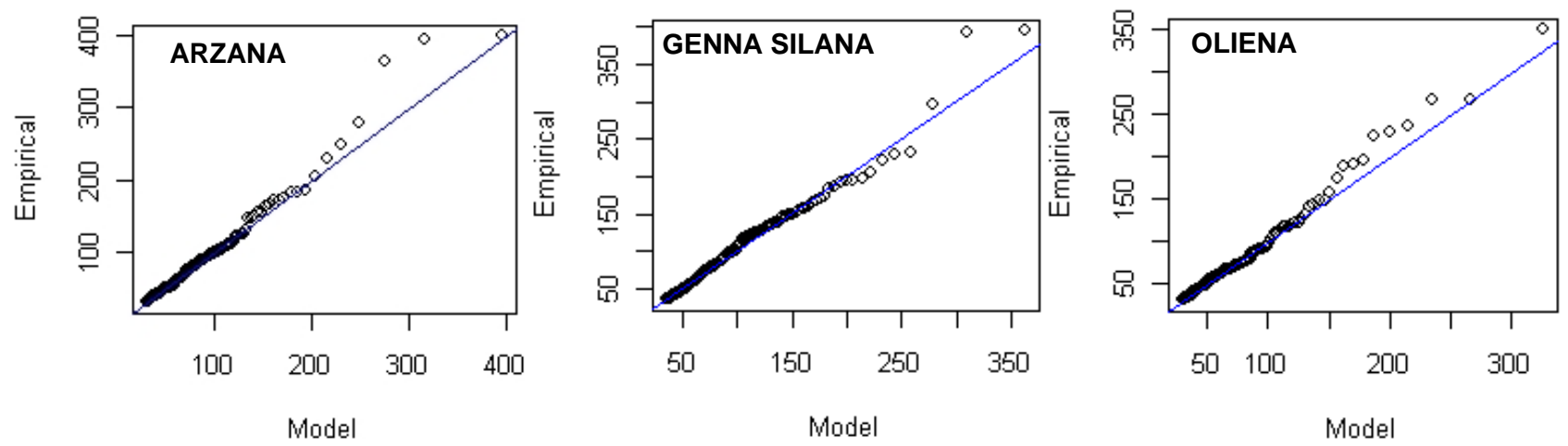

Fig. 4. QQ-plots showing model departures at Arzana, Genna Silana and Oliena.

Diagnostic plots generally suggest a good fit except for Arzana, Oliena and Genna Silana, as shown in Fig. 4. At Arzana and Genna Silana, this seems caused by an inadequate fitting of some high return time, while only short return times (less than 10 years) are not well fitted at Oliena.

When sampling variability is taken into account by confidence intervals (CIs) as in Table 6, the estimated model turns out to be adequate to explain observed data at Arzana and Genna Silana. Then we did not reject the model. The estimated model at Oliena has not been rejected as the main interest is in higher return levels. Figure 5 shows the three estimated GP distributions.

The estimated shape parameters and their $95 \%$ confidence intervals (Table 5) indicate that a Fréchet-type distribution $(\xi>0)$ is significantly adequate to describe exceedances at all but three sites: Baunei, Cala Gonone and Genna Silana. Here, we cannot reject the hypothesis of $\xi=0$, this implying a Gumbel distribution. As far as Baunei is concerned, this

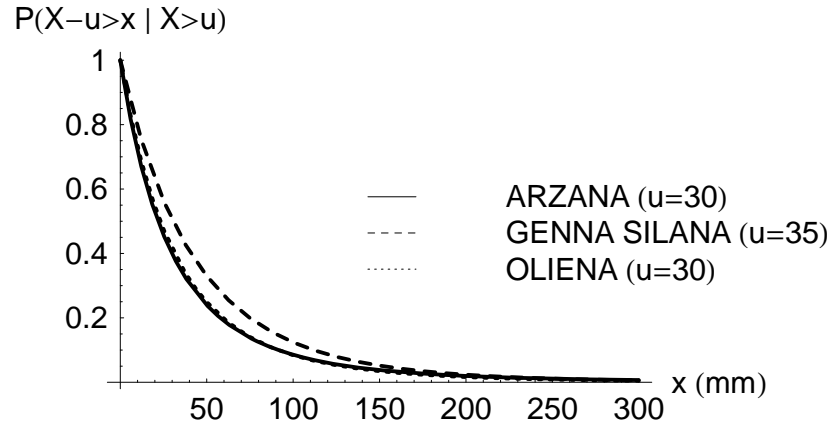

Fig. 5. Comparison among a few estimated Generalized Pareto distributions. On the $\mathrm{x}$-axis exceedances $x$ are indicated (in $\mathrm{mm}$ ), and on the $y$-axis the estimated probability of the exeedances, according to $(1)$. 
result reduces to its true proportions the conclusions coming from Sect. 4.1. In the case of Genna Silana, the confidence interval mostly includes positive values, and the fact that negative values are included as well may be due to the small sample size, (Koutsoyiannis, 2004a, b).

Some relevant return levels and their $95 \%$ CIs (by profile likelihood method) are compared in Table 6 and Fig. 6. We considered return levels only up to the 50 year-return time, as the limited availability of data makes 100 year-return levels unreliable, as proved by very large confidence intervals. We can note that Arzana, Genna Cresia and Villagrande in the Coastal Basin, and the stations in the Flumendosa Basin show the largest CIs. As far as Villagrande is concerned, this finding can be due to the smaller number of complete seasonal records ( 26 only, compared with at least 35 ) so that the uncertainty of the extrapolated return levels is higher here than at the other stations.

The return times of the EI values indicated in Table 2 have been finally computed in terms of number of daily observations, and are shown in Table 6. For instance, the value of $96.4 \mathrm{~mm}$ obtained for Baunei corresponds to a level that is exceeded on average once every 145 days, according to the GPD model estimated at Baunei on a seasonal basis.

\section{Discussion}

Daily rainfall data from 14 pluviometric stations located in Central-East Sardinia have been considered in order to capture possible trends of heavy rainfall in an area which is highly sensitive to the occurrence of extreme events. Indeed, the structure and the utilization of the soil make the Coastal Basin and its surroundings very vulnerable to both, desertification (Motroni and Canu, 2005) and damages from flash flood.

The descriptive analysis provides a first measure of the sensitivity of the Coastal Basin to heavy rainfall, which is confirmed by the time-return level assessment. According to GPD analysis, the daily value of $517.4 \mathrm{~mm}$ measured during the flood of December 2004 at Villanova Strisali, a station very close to Villagrande, belongs to the confidence interval of the 20 year-return level of the latter station. Although the Generalized Pareto model attaches low (conditional) probability (0.001) to events greater than $517.4 \mathrm{~mm}$ and suggests a return time of about 73.5 years, by taking into account all the uncertainty expressed by confidence intervals we will not be surprised by the occurrence of a new similar event in a shorter time.

The trend analysis provides a second sign: in the Coastal Basin, the autumn rainfall has remained essentially unchanged, while decreasing winter rainfall only marginally implies decreasing extreme events. Moreover, dry periods in spring and summer have remained unchanged, despite an increasing contribution of these seasons to both annual accumulation and annual frequency. (a)

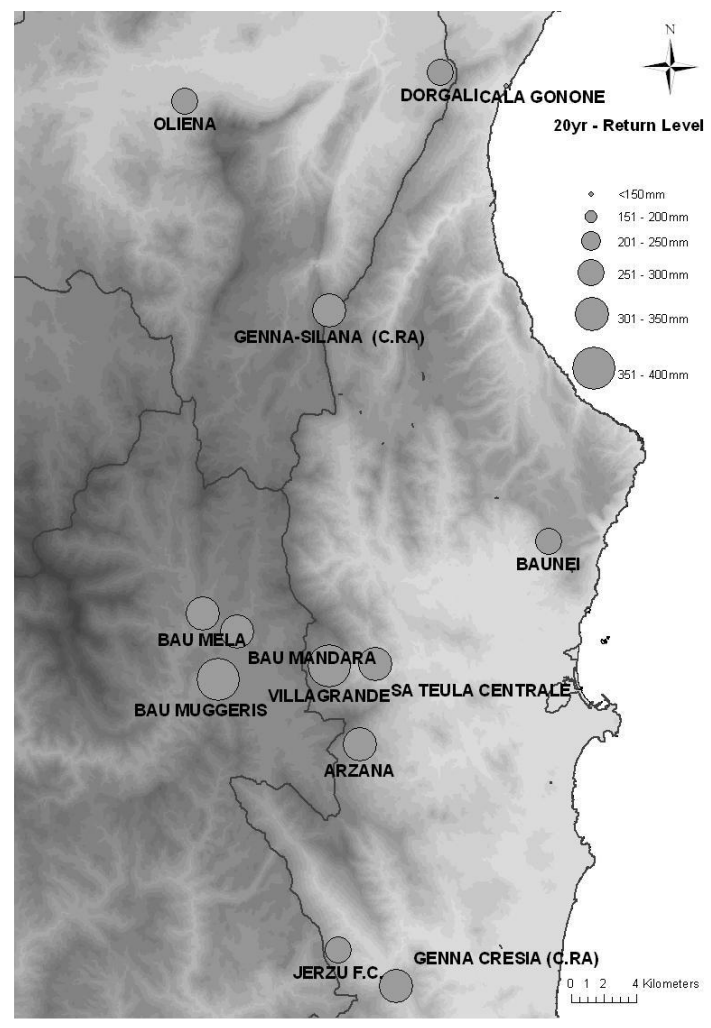

(b)

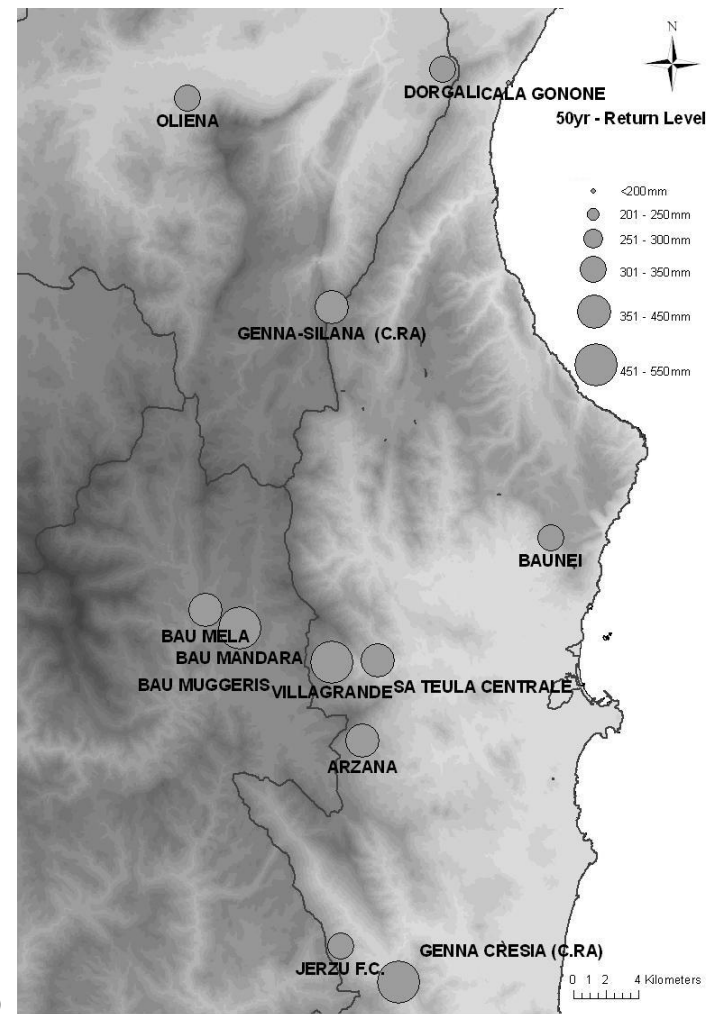

Fig. 6. Spatial representation of the estimated (a) 20 year- and (b) 50 year-return levels. 
Table 6. Estimated return levels $(\mathrm{mm})$ and their $95 \%$ confidence intervals for selected return times, by profile likelihood method. The last two columns report values EI and the corresponding return times, in number of days.

\begin{tabular}{|c|c|c|c|c|c|c|c|}
\hline Basin & Station & 20 years & 30 years & 40 years & 50 years & $\begin{array}{c}\mathrm{EI} \\
(\mathrm{mm})\end{array}$ & $\begin{array}{l}\text { return } \\
\text { times }\end{array}$ \\
\hline \multirow{8}{*}{ 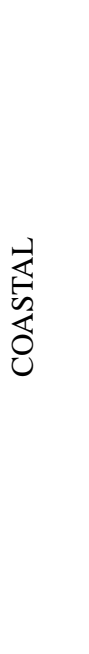 } & Arzana & $\begin{array}{c}\mathbf{3 3 5 . 3} \\
(252.7,516.9)\end{array}$ & $\begin{array}{c}\mathbf{3 8 2 . 5} \\
(279.0,628.0)\end{array}$ & $\begin{array}{c}\mathbf{4 1 9 . 2} \\
(298.4,708.7)\end{array}$ & $\begin{array}{c}\mathbf{4 4 9 . 7} \\
(314.0,784.0)\end{array}$ & 88.5 & 160 \\
\hline & Baunei & $\begin{array}{c}\mathbf{2 8 0 . 9} \\
(236.4,379.5)\end{array}$ & $\begin{array}{c}\mathbf{3 0 4 . 2} \\
(251.1,429.0)\end{array}$ & $\begin{array}{c}\text { 321.1 } \\
(261.2,467.1)\end{array}$ & $\begin{array}{c}\mathbf{3 3 4 . 4} \\
(268.8,498.6)\end{array}$ & 96.4 & 145 \\
\hline & Cala Gonone & $\begin{array}{c}\mathbf{1 4 3 . 4} \\
(122.8,189.1)\end{array}$ & $\begin{array}{c}\mathbf{1 5 4 . 0} \\
(129.9,210.5)\end{array}$ & $\begin{array}{c}\mathbf{1 6 1 . 5} \\
(134.8,226.7)\end{array}$ & $\begin{array}{c}\mathbf{1 6 7 . 3} \\
(138.4,239.9)\end{array}$ & 56.3 & 163 \\
\hline & Genna Cresia & $\begin{array}{c}\text { 333.1 } \\
(248.4,513.1)\end{array}$ & $\begin{array}{c}\text { 384.1 } \\
(276.4,624.4)\end{array}$ & $\begin{array}{c}\mathbf{4 2 4 . 2} \\
(297.4,717.2)\end{array}$ & $\begin{array}{c}457.9 \\
(314.5,798.5)\end{array}$ & 83.4 & 163 \\
\hline & Genna Silana & $\begin{array}{c}\mathbf{3 0 8 . 5} \\
(270.0,500.8)\end{array}$ & $\begin{array}{c}\mathbf{3 3 9 . 4} \\
(288.7,574.5)\end{array}$ & $\begin{array}{c}\mathbf{3 6 2 . 3} \\
(301.9,632.4)\end{array}$ & $\begin{array}{c}\mathbf{3 8 0 . 5} \\
(312.1,680.8)\end{array}$ & 96.1 & 151 \\
\hline & Jerzu & $\begin{array}{c}\mathbf{2 5 4 . 1} \\
(195.6,368.6)\end{array}$ & $\begin{array}{c}\mathbf{2 8 9 . 3} \\
(216.3,438.3)\end{array}$ & $\begin{array}{c}\mathbf{3 1 6 . 7} \\
(231.8,495.1)\end{array}$ & $\begin{array}{c}\mathbf{3 3 9 . 5} \\
(244.2,544.0)\end{array}$ & 67.0 & 146 \\
\hline & Sa Teula C. & $\begin{array}{c}\mathbf{3 2 3 . 4} \\
(248.7,467.1)\end{array}$ & $\begin{array}{c}\mathbf{3 6 9 . 9} \\
(276.3,557.1)\end{array}$ & $\begin{array}{c}\mathbf{4 0 6 . 1} \\
(270.0,630.7)\end{array}$ & $\begin{array}{c}\mathbf{4 3 6 . 2} \\
(313.7,694.1)\end{array}$ & 92.0 & 195 \\
\hline & Villagrande & $\begin{array}{c}\mathbf{3 5 8 . 2} \\
(265.2,581.1)\end{array}$ & $\begin{array}{c}\text { 403.1 } \\
(288.7,692.5)\end{array}$ & $\begin{array}{c}\mathbf{4 3 7 . 4} \\
(305.7,783.4)\end{array}$ & $\begin{array}{c}\mathbf{4 6 5 . 5} \\
(319.2,861.5)\end{array}$ & 110.0 & 187 \\
\hline \multirow{3}{*}{ 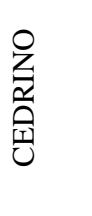 } & Dorgali & $\begin{array}{c}\mathbf{2 7 2 . 0} \\
(218.5,377.8)\end{array}$ & $\begin{array}{c}\mathbf{3 0 3 . 2} \\
(237.4,432.9)\end{array}$ & $\begin{array}{c}\text { 326.8 } \\
(251.2,487.5)\end{array}$ & $\begin{array}{c}\mathbf{3 4 5 . 9} \\
(261.9,528.4)\end{array}$ & 86.0 & 177 \\
\hline & Noce Secca & - & - & - & - & - & - \\
\hline & Oliena & $\begin{array}{c}\mathbf{2 5 8 . 1} \\
(202.9,381.1)\end{array}$ & $\begin{array}{c}\mathbf{2 9 1 . 1} \\
(222.3,453.9)\end{array}$ & $\begin{array}{c}\mathbf{3 1 6 . 3} \\
(236.3,513.2)\end{array}$ & $\begin{array}{c}\text { 336.8 } \\
(247.3,564.2)\end{array}$ & 75.2 & 199 \\
\hline \multirow{3}{*}{ 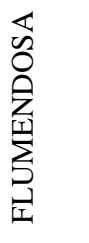 } & Bau Mandara & $\begin{array}{c}\mathbf{3 0 3 . 5} \\
(219.2,510.8)\end{array}$ & $\begin{array}{c}\mathbf{3 6 4 . 2} \\
(240.5,650.9)\end{array}$ & $\begin{array}{c}\mathbf{4 1 4 . 1} \\
(265.0,773.0)\end{array}$ & $\begin{array}{c}\mathbf{4 5 7 . 3} \\
(285.5,883.2)\end{array}$ & 61.5 & 177 \\
\hline & Bau Mela & $\begin{array}{c}\mathbf{3 0 8 . 7} \\
(228.7,512.7)\end{array}$ & $\begin{array}{c}\mathbf{3 5 3 . 3} \\
(252.2,629.5)\end{array}$ & $\begin{array}{c}\mathbf{3 8 7 . 9} \\
(269.4,727.6)\end{array}$ & $\begin{array}{c}\text { 416.6 } \\
(283.0,813.8)\end{array}$ & 70.4 & 151 \\
\hline & Bau Muggeris & $\begin{array}{c}\mathbf{3 5 8 . 3} \\
(246.2,643.8)\end{array}$ & $\begin{array}{c}\mathbf{4 2 3 . 2} \\
(277.1,820.6)\end{array}$ & $\begin{array}{c}\mathbf{4 7 5 . 5} \\
(300.5,974.6)\end{array}$ & $\begin{array}{c}\mathbf{5 2 0 . 1} \\
(319.5,1113.5)\end{array}$ & 72.2 & 160 \\
\hline
\end{tabular}

The results we obtained for a few stations in the Flumendosa Basin deserve careful consideration: while the descriptive analysis seems to present a less severe situation, the trend analysis shows that in autumn, extreme events have remained unchanged despite both total precipitation and frequency of rainy days have decreased. Moreover, even dryer springs are obtained. These results indicate that the negative impact of heavy rainfall on the territory can worsen. Negative effects can affect agriculture as well, since the occurrence of extreme events in autumn especially can be a hindrance to usual pasture and grazing management. These few remarks become more relevant when the results of the Extreme Values analysis are considered. Indeed, Table 6 shows that in the Flumendosa Basin, estimated 20-year return levels overcome $300 \mathrm{~mm}$ but, by taking into account sampling variability, CIs suggest that even daily rainfall higher than $400 / 500 \mathrm{~mm}$ can occur. In particular, here CIs have the largest upper bounds: they are comparable with those of Villagrande, but more reliable due to the higher number of records.
On the basis on these results, we stress that, as the most recent events have demonstrated, Governmental Authorities for environmental control and local administrators should improve land use planning by also applying suitable prevention systems. This might be done by comparing statistical information about heavy rainfall with several information layers about soil utilization, occurrence of wildfire, degree of urbanization and so on, as in Cossu et al. (2009a). In this respect, seasonal analysis has to be enhanced and time series of daily data modelled, to better understand the annual hydrological cycle, its possible changes and, in turn, their environmental and economic consequences. Moreover, further studies should include the consideration of the spatial dependence of extreme events, by considering multivariate models or spatial models (Coles, 1993; Padoan et al., 2010). This extension is particularly relevant for small study areas like that considered here. 
On the whole, the results presented here are coherent with those from similar analyses aiming at highlighting possible trends in Italy (Brunetti et al., 2001, 2004; Cislaghi et al., 2005) and, more in general, in the Mediterranean (Norrant and Douguédroit, 2006; Klein Tank and Können, 2003), and indicating that main signals of climate change are not significant. However, a direct comparison with the literature is made difficult by the fact that in this work a small area is considered. The mentioned literature usually presents results for extended areas which, however, often suffer for the sparse coverage of regions. The need of improved and updated time series has been reaffirmed many times, and it appears to be particularly important in areas, like the one considered here, where the orography contributes to determine a local climate. In many mountainous regions indeed, the monthly distribution of rainfall shows individual marked characteristics that make it representative just for a little station's surroundings. This makes even more relevant statistical analyses of observational data like the one presented here, aiming at improving the local climate knowledge and therefore, the understanding and validation capability of general models projections.

Acknowledgements. The authors are grateful to the referees for their careful reading of the paper and for useful suggestions, which led to a better and more complete presentation of the stated material, and stimulated future work. The authors would also like to thank G. Puligheddu, head of "Settore Idrografico dell' Assessorato ai Lavori pubblici della Regione Sardegna” for his help in searching for rain gauges metadata.

Edited by: S. Michaelides, K. Savvidou, and F. Tymvios Reviewed by: G. Ghiglieri and another anonymous referee

\section{References}

Alpert, P., Ben-Gai, T., Baharad, A., Benjamini, Y., Yekutieli, D., Colacino, M., Diodato, L., Ramis, C., Homar, V., Romero, R., Michaelides, S., and Manes, A.: The paradoxical increase of Mediterranean extreme daily rainfall in spite of decrease in total values, Geophys. Res. Lett., 29, 1536, doi:10.1029/2001GL013554, 2002.

Antonioli, F., Silenzi, S., Gabellini, M,. and Mucedda, M.: High resolution climate trend over the last 1000 years from a stalagmite in Sardinia (Italy), Quaternaria Nova, 7, 54-69, 2003.

Betrò, B., Bodini, A., and Cossu, Q. A.: Using a hidden Markov model to analyze extreme rainfall events in Central-East Sardinia, Environmetrics, 19, 702-713, 2008.

Bodini, A. and Cossu, Q. A.: Analisi della piovosità in Ogliastra (Sardegna, Italia) nel periodo 1951-1999, Milan, CNR-IMATI Technical Report, 08-04, available at: http://www.mi.imati.cnr. it/iami/abstracts/08-04.html, 2008 (in Italian).

Brunetti, M., Colacino, M., Maugeri, M., and Nanni, T.: Trends in the daily intensity of precipitation in Italy from 1951 to 1996, Int. J. Climatol., 21, 299-316, 2001.
Brunetti, M., Maugeri, M., Monti, F., and Nanni, T.: Changes in daily precipitation frequency and distribution in Italy over the last 120 years, J. Geophys. Res., 109, D05102, doi:10.1029/2003JD004296, 2004.

Chessa, P. A., Cesari, D., and Delitala, A. M. S.: Mesoscale regimes of precipitation and temperature over Sardinia (Italy) and the related synoptic-scale circulations, Theor. Appl. Climatol., 63, 195-221, 1999.

Cislaghi, M., De Michele, C., Ghezzi, A., and Rosso, R.: Statistical assessment of trends and oscillations in rainfall dynamics: analysis of long daily Italian series, Atmos. Res., 77, 188-202, 2005.

Coles, S. G.: Regional modelling of extreme storms via max-stable processes, J. Roy. Stat. Soc. B Met., 55, 797-816, 1993.

Coles, S.: An Introduction to Statistical Modelling of Extreme Values, Springer Verlag, London, 2001.

Cossu, Q. A., De Waele, J., and Di Gregorio, F.: Coastal Karst geomorphosites at risk? A case study: the floods of 6-11 December 2004 in central-east Sardinia, in: Natural and Anthropogenic Hazards in Karst Areas: Recognition, Analysis and Mitigation. Geological Society, edited by: Parise, M. and Gunn, J., London, Special Publications, 279, 85-95, doi:10.1144/SP279.8 03058719/07/, 2007.

Cossu, Q. A., Bodini, A., and Canu, S.: Vulnerabilità della regione Sardegna agli eventi estremi di precipitazione, in: Atti del " $12 \mathrm{mo}$ Convegno nazionale di Agrometeorologia", Sassari, 15-17 June 2009a (in Italian).

Cossu, Q. A., De Waele, J., Bodini, A., Sanna, L., and Cabras, S.: Peak discharge evaluation off ive exceptional flash floods of 2004-2008 in Central-East Sardinia karst areas and their geomorfological effectiveness (Italy), EGU General Assembly, Vienna, Austria, EGU2009-4066, 19-24 April 2009b.

De Waele, J.: Interaction between a dam site and karst springs: The case of Supramonte (Central-East Sardinia, Italy), Eng. Geol., 99, 128-137 doi:10.1016/j.enggeo.2007.11.010, 2008.

Delitala, A. M. S., Cesari, D., Chessa, P. A., and Ward, M. N.: Precipitation over Sardinia (Italy) during the 1946-1993 rainy seasons and associated large-scale climate variations, Int. J. Climatol., 20, 519-541, 2000.

Duce, P., Cesaraccio, C., Canu, S., Motroni, A., Dettori, M., Cocco, T., Antolini, G., and Zinoni, F.: Individuazione delle aree agricole e delle colture a forte rischio per variazioni climatiche, in: Risultati Conclusivi del Progetto finalizzato di ricerca "Climagri - Cambiamenti climatici e agricoltura”, Collana Climagri n. 51, CRA-UCEA, Roma, 79-91, ottobre 2006 (in Italian).

Frich, P., Alexander, L. V., Della-Marta, P., Gleason, B., Haylock, M., Klein Tank, A., and Peterson, T.: Global changes in climatic extremes during the 2 nd half of the 20th century, Clim. Res., 19, 193-212, 2002.

Gilleland, E. and Katz, R. W.: Tutorial for The Extremes Toolkit: Weather and Climate: Applications of Extreme Value Statistics, available at: http://www.assessment.ucar.edu/toolkit/(last access: 29 September 2009), 2005.

Haylock, M. and Nicholls, N.: Trends in extreme rainfall indices for an updated high quality data set for Australia, 1910-1998, Int. J. Climatol., 20, 1533-1541, 2000.

Klein Tank, A. M. G. and Können, G. P.: Trends in indices of daily temperature and precipitation extremes in Europe, 1946-99, J. Climate, 16, 3665-3680, 2003. 
Kostopoulou, E. and Jones, P. D.: Assessment of climate extremes in the eastern Mediterranean, Meteorol. Atmos. Phys., 89, 69$85,2005$.

Koutsoyiannis, D.: Statistics of extremes and estimation of extreme rainfall, 1, Theoretical investigation, Hydrolog. Sci. J., 49, 575590, 2004a.

Koutsoyiannis, D.: Statistics of extremes and estimation of extreme rainfall, 2, Empirical investigation of long rainfall records, Hydrolog. Sci. J., 49, 591-610, 2004b.

Leadbetter, M. R.: On extreme values in stationary sequences, Z. Wahrscheinlichkei., 28, 289-303, 1974.

Ludi, E.: Climate change, water and food security. Overseas Development Institute Background Note, ODI, London, March 2009

Miller, K. and Yates, D.: Climate Change and Water Resources: A Primer for Municipal Water Providers, AWWA Research Foundation, Denver, 2005.

Montagna, P., McCulloch, M., Mazzoli, C., and Silenzi, S.: B/Ca, $\mathrm{Sr} / \mathrm{Ca}, \mathrm{U} / \mathrm{Ca}$ and $\mathrm{Mg} / \mathrm{Ca}$ ratios of a non-tropical coral (Cladocora caespitosa) from the Northern Adriatic Sea (Mediterranean Sea) and their relationship to sea surface temperature, 10th International Coral Reef Symposium, Okinawa, Japan, Abstract book, 269 pp., 28 June-2 July 2004.
Motroni, A. and Canu, S.: Climate indicators for assessing sensitive areas to drought and desertification in Sardinia (Italy), Proceedings of WMO/FAO/Cost Action Workshop on "Climatic analysis and mapping for agriculture", 2005.

Norrant, C. and Douguédroit, A.: Monthly and daily precipitation trends in the Mediterranean (1950-2000), Theor. Appl. Climatol., 83, 89-106, 2006.

Osborn, T. J. and Hulme, M.: Evidence for trends in heavy rainfall events over the UK, Philos. T. R. Soc. A, 360, 1313-1325, 2002.

Padoan, S., Ribatet, M., and Sisson, S. A.: Likelihood-based inference for max-stable processes, JASA, Theory and Methods, in press, 2010.

Peterson, T. C., Folland, C., Gruza, G., Hogg, W., Mokssit, A., and Plummer, N.: Report on the activities pf the Working Group on Climate Change Detection and Related Rapporteurs 19982001, World Meteorological Organization, Geneva, Switzerland, Report WCDMP-47, WMO-TD 1071, 2001.

Vörösmarty, C. J., Green, P., Salisbury, J., and Lammers, R. B.: Global Water Resources: Vulnerability from Climate Change and Population Growth, Science, 289(5477), 284-288, 2000.

Walther, G. R., Post, E., Convey, P., Menzel, A., Parmesan, C., Beebee, T. J. C., Fromentin, J. M., Hoegh-Guldberg, O., and Bairlein, F.: Ecological responses to recent climate change, Nature, 416, 389-395, 2002. 